\title{
STUDI ANALISA DATA STORAGE DENGAN MENGGUNAKAN SISTEM NAS-DAS-SAN
}

\author{
Budiya Surya Putra, S.Kom.* \\ Timothy John Pattiasina, ST., M.Kom. ${ }^{*}$
}

\begin{abstract}
ABSTRAK
Teknologi storage (penyimpanan) berkembang cukup pesat. Sampai saat ini, begitu banyak teknologi storage yang tersedia, dengan segala macam keunggulan dan keterbatasan. Di antara teknologi storage yang telah dikenal adalah DAS (Direct Attached Storage), NAS (Network Attached Storage), dan SAN (Storage Area Network).

Tujuan penelitian makalah ini, untuk memahami cara kerja data data storage dan memahami kelebihan menggunakan sistem NAS, DAS, SAN.

Hasil penelitian membuktikan bahwa terdapat aspek-aspek tertentu yang harus dipertimbangkan dalam pemilihan penagaman data pada sistem penyimpanan data di dalam suatu jaringan komputer.
\end{abstract}

Kata Kunci: DAS, NAS, SAN

\section{PENDAHULUAN}

Beberapa tahun belakangan ini penggunaan teknologi mengalami kemajuan yang sangat pesat. Hal ini dibuktikan dengan banyaknya area hotspot yang dipasang pada tempat-tempat umum oleh pihak ISP (pihak penyediaan jasa layanan internet), baik itu di pertokoan maupun perkantoran. Sistem penyimpanan data (storage) pada saat ini telah dikembangkan dalam bentuk terdistribusi yang berjalan pada sistem jaringan computer.

\subsection{Latar Belakang}

Data adalah segala sesuatu yang dapat disimpan dalam memori menurut format tertentu. Storage adalah tempat menyimpan instruksi program dan data keperluan penggunaan dengan komputer. Data Storage adalah salah satu alat terpenting dalam rangkaian alat yang berada di suatu komputer.

DAS (Direct Attached Storage) adalah merupakan storage yang menempel langsung (point-to-point) pada server atau komputer kita. NAS (Network Attached Storage) adalah storage hard disk yang dikonfigurasi dengan memberikan IP Addres dan dipasang di jaringan $L A N$ (bukan dengan cara memasang langsung di komputer yang menjalankan aplikasi), sehingga dapat diakses oleh beberapa user sekaligus. SAN (Storage Area Network) adalah sebuah jaringan berkecepatan sangat tinggi, yang terdiri dari server dan penyimpanan. Terpisah dan berbeda dengan LAN / WAN. SAN tersambung melalui fiber channel, serabut optic berkedepatan tinggi atau kabel tembaga untuk mnenginterkoneksikan perangkat server dan penyimpanan.

\footnotetext{
* Staf Pengajar Program Studi D3-Manajemen Informatika IKADO

* Staf Pengajar Program Studi S1-Teknik Informatika IKADO
} 


\subsection{Perumusan Masalah}

Perumusan masalah dalam penelitian ini adalah :

1. Bagaimana kita dapat memahami cara kerja data storage.

2. Bagaimana kita dapat memahami data storage dengan menggunakan sisten NAS, SAN, DAS.

3. Bagaimana NAS dapat lebih unggul dari DAS maupun $S A N$.

\subsection{Tujuan dan Manfaat Penelitian}

Tujuan dari penelitian ini adalah :

1. Agar kita dapat menegerti cara kerja data storage.

2. Agar kita dapat memahami data storage dengan menggunakan $N A S, S A N$, dan DAS.

Untuk manfaat penelitian ini adalah agar dapat mengerti teori data storage secara luas dan mengerti fungsi dari NAS, SAN, dan DAS.

\section{LANDASAN TEORI}

Teknologi storage memang terus berkembang seiring dengan perkembangan kehidupan digital. Dari perkembangan ini, ssat ini tersedia 3 jenis model teknologi data storage yang banyak digunakan. Teknologi tersebut adalah DAS, NAS, dan SAN. Teknologi ini mendukung kebutuhan user dalam skema aplikasi dan lingkungan yang berbeda-beda.

\subsection{Pengertian Direct Attached Storage (DAS)}

Sistem DAS ini merupakan teknologi yang paling sederhana dan paling umum digunakan di dalam berbagai kehidupan digital. Sistem DAS ini akan banyak ditemukan di dalam server-server, stand alone PC, workstation. Jalur komunikasi yang digunakan antara $P C$ dengan media penyimpanan ini adalah menggunakan sistem standar bus yang biasa digunakan untuk koneksi antara harddsik dengan sistem komputer. Seperti misalnya SCSI, ATA, Serial ATA (SATA) dan Fiber Channel (CF).

Sistem DAS ini selalu terkait pada $P C$ atau perangkat komputer individual untuk dapat digunakan. Dengan demikian, DAS juga akan bergantung kepada sistem operasi dan performa dari $P C$ yang digunakan. Dengan demikian, DAS memiliki semua kelemahan yang ada pada $P C$ tersebut. Penambahan dan pengurangan harddisk akan sangat berpengaruh terhadap performa keseluruhannya, sehingga downtime system storage ini mungkin saja terjadi. Probabilitas data hilang juga cukup tinggi di dalam sistem DAS karena tidak ada sistem back-up yang pasti.

\subsection{Pengertian Network Attached Storage (NAS)}

NAS secara umum dapat diartikan sebagai sekelompok media penyimpanan yang secara langsung terkoneksi ke dalam jaringan local (LAN) dengan menggunakan file sistem khusus jaringan seperti NFS dan CIFS. Perbedaan yang mencolok antara NAS dan SAN adalah NAS melakukan semua transaksi keluar masuk data dalam jaringan pada tingkatan file-level, sedangkan SAN melakukannya pada tingkatan block-level. Pengertian file-level adalah NAS melakukan pembacaan permintaan dan kemudian melakukan transaksi data dalam bentuk file yang sudah jadi dan siap dibaca oleh perangkat komputer yang memintanya. Semua permintaan dan perintah yang berhubungan dengan di dalamnya diterjemahkan terlebih dahulu oleh perangkast NAS menjadi sebuah perintah yang menjalakan transaksi dalam tingkatan file-level. 
Orientasinya pada file-level sangat cocok untuk diterapkan pada jaringan yang berheterogen yang terdiri dari bermacam-macam sistem di dalamnya. Implementasi NAS juga tidak membutuhkan banyak perubahan pada desain jaringan yang telah berjalan.

\subsection{Pengertian Storage Area Network (SAN)}

Dari teknologi, SAN tidak banyak yang berbeda dengan NAS. Hanya saja, yang menjadi perbedaan utama dan yang paling menonjol adalah perbedaan mekanisme transfer data. Mekanisme transfer data dari perangkat komputer yang digunakan menuju ke media penyimpanan dalam sistem $S A N$ yang tidak dilakukan dalam tingkatan filelevel melainkan dalam tingkat block-level. SAN menggunakan Fiber Channel atau Ethernet sebagai koneksi antara perankat komputer dengan media penyimpanannya kini sudah menjadi bagian yang terpisah.

Sistem storage SAN berada dalam segmen jaringan yang terpisah dengan $L A N$ yang sehari-hari digunakan. Hal ini bertujuan untuk mengurangi interferensi dengan komunikasi-komunikasi lainnya dalam jaringan local, sehingga proses transfer data apalagi blok data yang sensitive terhadap latensi tidak terganggu.

Switch memberikan beberapa keuntungan dalam lingkungan $S A N$, antara lain :

1. Jika suatu switch gagal dalam sebuah lingkungan jalinan switch, maka switch lainnya biasanya masih operasional. Berbeda dengan $\mathrm{Hub}$, jika terjadi kegagalan, maka seluruh sistem gagal.

2. Switch mendukung standar Fiber Channel Switch (FC-SW), memungkinkan pengamatan yang independen dari lokasi subsistem di jalinan fiber, dan memberikan isolasi yang lebih baik untuk mencegah kegagalan yang pada akhirnya meningkatkan ketersediaan infrastruktur.

\section{ANALISA DATA STORAGE}

Model penyimpanan tradisional melibatkan sebuah harddisk dan susunan disk atau sebuah sistem RAID yang ditempelkan secara langsung ke sebuah server atau mesin desktop, dan dikenal dengan nama DAS. Model ini masih banyak dipakai, tetapi tidak dapat memenuhi kebutuhan masa depan, dikarenakan model ini menyebarkan data secara meluas di antara banyak server. DAS dianggap tidak efisien dan tidak cocok untuk mengatur penyimpanan yang besar di dalam sebuah linkungan jaringan. Oleh karena itu DAS mulai tergantikan oleh NAS dan SAN.

Aplikasi NAS penting dalam spesialisasi server untuk mengoptimalkan pembagian file ke dalam jaringan dan di antara kerangka yang berbeda-beda. Dengan cara yang sederhana hanya menempelkanalat tersebut ke dalam jaringan, bagian IT dapat dengan cepat dan mudah mengembangkan kapasitas jaringan penyimpanan. Selain Integrasi dengan jaringan yang merupakan salah satu kekuatan rancangan NAS, hal ini uga membawa ke dalam pembatasan yang besar. Karena sistem penyimpanan membagi ke dalam jaringan yang sama dengan klien dan aplikasi server. Lalu lintas data yang berat dapat menyebabkan efek yang tidak diinginkan, seperti bottleneck dan mengurangi penampilan jaringan.

Untuk $S A N$ menghindari hal in dengan menciptakan alat yang terpisah, jaringan dedikasi, dihungkan ke jaringan dengan software khusus dan penghubung. Kerangka $S A N$ memungkinkan data yang terpusat dan solusi manajemen yang berskala besar yang dapat memaksimalkan penampilan sistem dengan memindahkan data ke lalu lintas jaringan yang regular. 
Meskipun kebutuhan untuk penyimpanan jelas, tidak berarti selalu jelas untuk solusi yang tepat bagi organisasi. Ada berbagai pilihan yang tersedia, yaitu DAS, NAS, $S A N$. Untuk memlih solusi storage tergantung pada kebutuhan khusus dan jangka panjang tujuan bisnis organisasi masing-masing. Beberapa kriteria untuk mempertimbangkan adalah :

1. Kapasitas yaitu jumlah dan jenis data yang perlu disimpan dan dibagi.

2. Kinerja yaitu $I / O$ dan persyaratan throughput.

3. Skalabilitas yaitu jangka panjang data.

4. Ketersediaan dan keandalan yaitu bagaimana mission-critical adalah aplikasi yang digunakan.

5. Perlindungan data yaitu backup.

6. Staf IT dan sumber daya yang tersedia.

\subsection{Direct Attached Storage}

DAS adalah tingkat paling dasar penyimpanan, dimana perangkat penyimpanan data merupakan bagian dari komputer host, seperti drive atau langsung terhubung ke server tunggal, seperti array RAID. Demikian dengan jaringan workstation harus mengakses server dalam rangka untuk menyambung ke perangkat penyimpanan. Hal ini berbeda dengan jaringan penyimpanan NAS dan SAN yang terhubung ke workstation dan server memalui jaringan. Ketika model pertama penyimpanan, produk DAS masih terdiri dari mayoritas yang diinstall dengan dasar sistem penyimpanan dalam infrastruktur IT saat ini.

DAS sangat cocok untuk berbagai file lokal dengan server tunggal atau beberapa server. Misalnya, usaha kecil atau departemen dan kelompok kerja yang tidak memerlukan berbagi informasi dalam jarak jauh atau di perusahaan. Perusahaan keil menggunakan DAS untuk melayani dan e-mail, sementara perusahaan besar menggunakannya dalam campuran penyimpanan mungkintergolong NAS dan SAN. DAS juga menawarkan kemudahan manajemen dan administrasi, karena dapat dikelola menggunakan jaringan sistem operasi dari server. Namun kompleksitas manajemen dapat meningkat dengan cepat dengan penambahan server baru, karena penyimpanan untuk setiap server harus diberikan secara terpisah.

\subsection{Network Attached Storage}

Penyimpanan jaringan dikembangkan untuk menghadapi tantangan yang inheren dalam server berbasis infrastruktur seperti DAS. NAS adalah storage harddisk yang dikonfigurasi dengan memberikan IP Addres dan dipasang di jaringan $L A N$, sehinnga dapat diakses oleh beberapa user sekaligus. Dengan cara memindahkan akses ke storage beserta manajemennya dari server seperti ini, maka program aplikasi dan file dapat diakses lebih cepat, tidak menggunakan resource prosesosr yang sama lagi. Seperti telah dibahas sebelumnya, server memiliki fungsi ganda file sharing dan aplikasi yang melayani model DAS yang menyebabkan jaringan slowdown. NAS merupakan server penyimpanan dan menyediakan lebih banyak fleksibilitas dalam akses data berdasarkan independent.

NAS merupakan pilihan yang tepat untuk mencari biaya sederhana dan cara efektif untuk mencapai akses data yang cepat untuk beberapa klien tingkat file. NAS bermanfat dari peningkatan kinerja dan produktifitas. Dipopulerkan pertama sebagai entry-level atau solusi midrange, NAS masih memiliki basis menginstall terbesar dalam usaha kecil dan sector menengah bisnis. Namun keunggulan NAS adalah kesederhanaan 
dan nilai yang sama-sama berlaku untuk suatu perusahaan. Perusahaan kecil menemukan NAS menjadi solusi plug and play yang mudah untuk menginstall, dan mengelola dengan atau tanpa tangan IT. Karena kemajuan teknologi disk drive, mereka juga memperoleh biaya yang lebih rendah.

\subsection{Storage Area Network}

SAN adalah network private yang menghubungkan server dan unit penyimpanan. Terpisah dan berbeda dengan perusahaan $L A N$ / WAN, tujuan utama SAN adalah untuk menangani trafik data dalam jumlah besar antara server dan peralatan penyimpanan, tanpa mengurangi bandwidth yang ada di LAN / WAN. Biasanya tersambung melalui Fiber Channel, sebuah teknologi komunikasi data berkecepatan sangat tinggi, menjadikan SAN sebuah jaringan dedicated yang platform-independent yang beroperasi di belakang server. SAN terdiri dari infrastruktur komunikasi yang memberikan sambungan fisik dan lapisan manajemen yang mengatur sambungan, elemen penyimpanan, dan sistem komputer sehingga menghasilkan transfer data yang sangta aman dan handal.

Adapun keuntungan yang terdapat dalam $S A N$ yaitu satu copy dari data jadi dapat diakses oleh semua host melalui jalur yang berbeda dan semua data lebih efisien dimanagenya. Untuk infrastruktur transport data yang dapat menjamin tingkat kesalahan yang sangat minimal, dan kemampuan dalam mengatasai kegagalan. Dengan skalabilitas server maupun media penyimpanan dapat ditambahkan secara independent satu atau lainnya, dengan tanpa pembatas harus menggunakan sistem yang proprietary. Karena pertambahan tingkat redundansi dan kemampuan manajemen yang baik, maupun kemampuan untuk ditambahkan server dan media penyimpanan secara independent, SAN akhirnya memungkinkan biaya kepemilikannya yang rendah pada saat yang sama menaikkan Return On Information Management (ROIM) dibandingkan metode penyimpanan tradisional.

\subsection{Aspek-Aspek Keamanan Data}

Di dalam keamanan data pada storage networking terdapat lima aspek utama yaitu :

1. Confidentiality (Kerahasiaan)

Confidentiality di dalam sudut pandang keamanan adalah menunjukkan bahwa tidak satu yang dapat mengakses data kecuali yang berhak. Confidentiality berhubungan dengan data yang diberikan ke pihak lain untuk keperluan tertentu.

2. Integrity (Keutuhan)

Integrity berkaitan dengan konsistensi informasi yang terdapat pada data yang disimpan di dalam storage. Dimana modifikasi ataupun pengrusakan data yang mengakibatkan ketidakutuhan data ditimbulkan oleh yang bersifat kecelakaan ataupun oleh malicious code.

3. Authebticaltion (Keaslian)

Authebticaltion berkaian dengan menjaga keaslian informasi di dalam data yang diberikan atau yang disimpan oleh sistem storage dan darimana data / informasi itu berasal, selain itu juga menjaga keaslian kepemilikan dari data tersebut, dengan kata lain menjaga keaslian kepemilikan yang berhak mengakses data tersebut. 
4. Availability (Ketersediaan)

Availability pada keamanan data pada storage adalah sesuatu yang berhubungan dengan ketersediaan informasi ruang, waktu dan representasi data yang dibutuhkan oleh pemilik yang hak di dalam suatu periode waktu. Sistem storage yang baik dapat mencegah masalah Dos attack (Denial of Service Attack) diaman serangan ini menghambat user yang berhak untuk mendapatkan informasi atau data yang dibutuhkan.

5. Non Repudiaton (Tidak Ada Penyangkalan)

Non Repudiaton berkaitan dengan menjaga user atau pemilik data tidak dapat menyangkal telah mengakses atau menggunakan data sehingga sistem mengetahui siapa yang bertanggung jawab terhadap apa yang telah terjadi oleh data tersebut.

\subsection{Kriptografi pada sistem penyimpanan data}

Data yang disimpan pada sebuah storage device kebanyakan mempunyai sifat rahasia ataupun bersifat pribadi, sehingga data-data tersebut harus diamankan dari pihak ketiga. Salah satu caranya adalah dengan menggunakan Kriptografi. Tujuannya menggunakan metode ini adalah :

1. Kerahasiaan

Memberikan kerahasiaan data dan menyembunyikan informasi dengan menggunakan teknik-teknik enkripsi.

2. Keutuhan Data

Memberikan jaminan untuk setiap bagian dari data tidak mengalami perubahan dari saat dibuat sampai dengan saat disimpan.

3. Keaslian

Mengindentifikasi keaslian suatu data dan memberikan jaminan bahwa data tersebut berasal dari pihak yang berwenang, serta menguji identitas dari pihak yang akan mengakses data.

4. Tidak ada penyangkalan

Membuktikan bahwa data tersebut berasal dari pihak yang berwenang, sehingga pihak tersebut tidak dapat menyangkal atas kepemilikan data tersebut.

\subsubsection{Dua Kategori Utama dari Kriptografi}

Kriptografi mempunyai dua kategori yang utama yaitu :

1. Kriptografi simetrik

Kriptografi ini biasanya juga disebut dengan single key cryptosystem, menggunakan 2 buah kunci yang sama untuk proses enkripsi dan dekripsinya. Dimana kunci enkripsi tersebut dibuat oleh pihak yang mengirimkan atau membuat data, kemudian kunci tersebut dikirimkan kepada pidahk yang menerima data tersebut untuk melakukan deskripsi.

2. Kriptografi asimetri

Kriptografi ini menggunakan 2 buah kunci yang berbeda, 1 buah enkripsi dan 1 lagi untuk dekripsi, diaman kunci untuk enkripsi bersifat terbuka atau publik, sedangkan untuk dekripsi bersifat rahasia atau pribadi. Kunci public disimpan dan didistribusikan oleh pihak yang berwenang yaitu Certified Authorizied, dimana kumpulannya adalah Public Key Infrastructure. Maka kategori ini sering disebut PKI Cryptographic. Sedangkan kunci pribadi disimpan tidak disebarkan. 


\subsection{Algoritma Kriptografi}

Di dalam kriptografi terdapat banyak algoritma-algoritma yang dikembangkan untuk proses enkripsi dan dekripsi. Pada kesempatan kali ini akan membahas sekilas tenntang algoritma kriptografi.

\subsubsection{Algoritma Triple- DES}

Algoritma ini termasuk dalam kategori kriptografi simetris. Algoritma ini adalah pengembangan dari algoritma DES yang mempunyai banyak kelemahan. Cara kerja dari algoritma ini didasarkan oleh algoritma DES yaitu dengan cara melakukan proses enkripsi DES sebanyak 3 kali dengan mengambil 3 kunci sebanyak 64 bit dari seluruh kunci yang mempunyai panjang 192 bit.

\subsubsection{Algoritma IDEA}

IDEA (International Data Encryption Algorithm) dikembangkan pada tahun 1990 di Swiss oleh kriptografer ternama James Massey dan Xuejia Lai. Algoritma ini termasuk kategori kriptografi simetrik dengan menggunakan kunci sepanjang 128 bit. Algoritma blok chipper text dalam IDEA beroperasi dengan menggunakan 64 bit plaintext dan blok chipertext yang dikendalikan oleh 12 inovasi dasar dalam desain algoritmanya yang berbentuk suatu tabel.

\subsubsection{Rivest Code (RC) 4}

RC4 merupakan salah satu algoritma kunci simetris yang bebrbentuk stream chipper, algoritma ini ditemukan pada tahun 1987 oleh Ronal Rivert dan menjadi simbiol keamanan RSA. RC4 menggunakan variable yang panjang kuncinya dari 1 sampai dengan 256 bit.

Algoritma RC4 bekerja dalam 2 fase yaitu key setup dan ciphering Key setup adalah fase pertama dan yang paling sulit dari algoritma ini. Selama key setup N bit menghasilkan dan kunci serta jumlah $\mathrm{N}$ dari operasi pencampuran. Pencampuran tersebut terdiri dari penukaran bit, operasi modulo adalah hasil sisa dari proses pembagian.

\section{Keunggulan NAS terhadap SAN dan DAS}

Penelitian ini memberikan menjelaskan mengapa yang berkembang belakangan ini adalah data storage NAS. Penelitian ini memberikan penjelasan singkat mengenai variasi penyimpanan utama, kemudian akan mengembangkan konsep dalam cara yang lebih terstruktur.

1. DAS

Storage secara langsung terpasang oleh sebuah kabel ke prosesor komputer. I/O juga disebut protocol yang mengakses perangkat secara langsung.

2. NAS

Sebuah perangkat $N A S$ prosesornya ditambah penyimpanan disk, yang melekat pada TCP/IP yang berbasis jaringan LAN dan WAN dan diakses menggunakan khusu file akses / file sharing protocol. Permintaan file diterima oleh NAS yang diterjemahkan oleh prosesor untuk permintaan perangkat internal.

3. SAN

Storage berada di jaringan khusus. Seperti $D A S, I / O$ akses permintaan perangkat secara langsung. SAN Fiber Channel menggunakan media apapun untuk koneksi prosesor apapun dan penyimpanan pada jaringan. 


\title{
4.1. Rancangan Server Protect for NAS
}

Server Protect for NAS menggunakan rancangan tiga rangkaian dari Server Protect untuk melindungi penyimpanan data pada alat penyimpanan yang terhubung. Pada Server Protect for NAS, Norma; Server dikenal sebagai Scan Server.

\author{
4.2. Bentuk dan Keuntungan NAS Solutions Virus Scanning Protects Data Integrity \\ Bentuk dan keuntungan dari NAS terdiri daari bebeapa macam diantaranya \\ yaitu : \\ 1. Updating Otomatis \\ 2. Manajemen terpusat melalui Rancangan Tiga Rangkaian \\ 3. Scalability dan High Performance \\ 4. Comprehensive Log Reports
}

\section{KESIMPULAN DAN SARAN}

Data-data perusahaan atau pemerintah yang disimpan di dalam Data Storage mempunyai aspek keamanan data yaitu kerahasiaan, keaslian, ketersediaan, dan keutuhan data.

\subsection{Kesimpulan}

Aspek-aspek yang harus dipertimbangkan dalam pemilihan pengamanan data pada sistem penyimpanan data di dalam suatu jaringan komputer. Adapun aspek-aspek tersebut adalah :

1. Kualifikasi vendor yang bertanggung jawab atas sistem keamanan.

2. Keamanan Data.

3. Manajemen Data.

4. Pertimbangan Operasional.

5. Pertimbangan Pelayanan.

\subsection{Saran}

Kebutuhan sistem storage saat ini memang tidak bias ditunda-tunda. Semakin berkembangnya kehidupan digital, semakin penting teknologi sistem storage beserta media penyimpanannya untuk diperhatikan. Perkembangan teknologi storage masih akan terus berlanjut, tidak hanya terbatas pada ketiga sistem ini saja.

\section{DAFTAR PUSTAKA}

Dennis, A, B.H. Wixom, and D. Tegarden, 2005, System Analysis and Design with UML version 2.0 : An Object Oriented Approach, John Wiley and Son, Inc.

Lukas, Jonathan, 2006 , Jaringan Komputer, Yogyakarta : Graha Ilmu.

Kercheval, Berry. 2002, DHCP Panduan untuk Konfigurasi Jaringan TCP/IP yang Dinamis,

Yogyakarta : Penerbit Andi.

Jogiyanto, HM, Akt, MBA, Ph.D, 1990, Analisis Dan Desain Sistem Informasi, Yogyakarta : Andi.

Widyaharton, Bob, 1984, Beberapa Segi Penyajian Informasi dan Pengenalan Komputer.

Bandung : Alumni. 